\title{
New Disease Reports \\ First report of Diplodia seriata causing canker on Castanea sativa in India
}

M. $\operatorname{Dar}^{1}$ and M. Rai ${ }^{2 *}$

\begin{abstract}
${ }^{1}$ Division of Genetics and Plant Breeding, Faculty of Agriculture, Sher-e-Kashmir University of Agricultural Science and Technology - Kashmir, Wadura, Jammu and Kashmir 19320, India; ${ }^{2}$ Department of Biotechnology, Sant Gadge Baba Amravati University, Amravati-444602, Maharashtra, India
\end{abstract}

*E-mail: mkrai123@rediffmail.com

Received: 13 Nov 2016. Published: 20 Apr 2017. Keywords: chestnut, Cryphonectria, Gnomoniopsis, ITS

In India, sweet chestnut (Castanea sativa) trees are affected by pathogenic fungi including species of Cryphonectria and Gnomoniopsis (Dar \& Rai, 2014; Dar \& Rai, 2015). During a survey of fungal pathogens associated with cankers of chestnut trees in Jammu and Kashmir State, India, $60 \%$ of the trees were found to be infected by Diplodia seriata. The cankers were formed mostly on branches and stem often exposing xylem tissue. The bark was broken into a scar and the infection continued vertically to form cankers on one side of the stem (Fig.1).

Bark pieces of 5-6 cm were taken from the edge of cankers bearing fruiting structures and cut with a cork borer. These were surface sterilised with $90 \%$ ethanol for 60 seconds and placed on potato dextrose agar (PDA). The PDA plates were incubated at room temperature $\left(25 \pm 2^{\circ} \mathrm{C}\right)$ and fungal growth was observed within eight days. A total of ten isolates of $D$. seriata were isolated. Representative cultures were deposited in the culture collection of the Sant Gadge Baba Amravati University with accession numbers DBT201-202, and DBT251-252.

The samples infected with Diplodia had pycnidial conidiomata which were dark in colour present separately, wrapped up with host bark, coming out of the bark at maturity and becoming emergent and ostiolate. Conidiogenous cells measured 3-5.5 $\times 7-10 \mu \mathrm{m}$ and were hyaline, thin-walled, smooth, cylindrical, swollen at the base, separate, producing single conidia at the tip. Conidia were 22-25 $\times$ 9.5-11 $\mu \mathrm{m}$ with a distinct basal scar, hyaline moderately thick and smooth walled, generally septate sometimes aseptate, ovoid, thicker in middle near septa, apex obtuse, base rounded and slightly bent to one side (Fig. 2). The morphological characters fitted the description of $D$. seriata by Phillips et al. (2007). Colonies on PDA initially appeared white in colour but produced light dark-green melanised hyphae and pycnidia within seven days of incubation at room temperature changing the whole colour of the colony to greyish-green. The colonies were produced with rough and irregular margins. ITS sequences of representative isolates were amplified and sequenced as described by Nilsson et al. (2008) (GenBank Accession Nos. KC963912, KC963913, KC963917 and KC963918). The ITS sequence showed 99\% similarity to isolates of D. seriata (KR822800, KJ463386, KF535906 and KF535904).

Koch's postulates (Fig. 3) were done using young (two-three years old) healthy stems of chestnut trees. The stems were surface-sterilised with $2 \%$ sodium hypochlorite, wounded with a sterile cork borer $(6 \mathrm{~mm})$ and inoculated with a mycelial plug. The plugs were protected with moistened cotton and sealed with paraffin film. The controls were inoculated as above with sterile PDA. Inoculations were made in November 2013 using three plants per isolate. In January 2014, the fungus was re-isolated from the stem lesions. The identity of the pathogen was confirmed using morphological characters. This is to our knowledge the first report of Diplodia seriata causing cankers on sweet chestnut.

\section{Acknowledgements}

Mr. Dar gratefully acknowledges the financial support as Junior Research Fellow by the University Grants Commission, New Delhi, Government of India.

\section{References}

Dar MA, Rai M 2014. Occurrence of Cytospora castanae sp. nov., associated with perennial cankers of Castanea sativa. Mycosphere $\mathbf{5}$, 747-757.

Dar MA, Rai M, 2015. Gnomoniopsis smithogilvyi, a canker causing pathogen on Castanea sativa: First report. Mycosphere 6, 327-336.

Downes FP, Ito K, eds, 2001. Compendium of Methods for the Microbiological Examination of Foods. 4th ed. Washington D.C., USA: American Public Health Association. http://dx.doi.org/10.2105/9780875531755

Nilsson RH, Ryberg M, Kristiansson E, Abarenkov K, Larsson K-H Kõljalg U, 2006. Taxonomic reliability of DNA sequences in public sequence databases: a fungal perspective. PLOS ONE 1, e59. http://dx.doi.org/10.1371/journal.pone.0000059

Phillips AJL, Crous PW, Alves A, 2007. Diplodia seriata, the anamorph of "Botryo- sphaeria" obtusa. Fungal Diversity 25, 141-155.

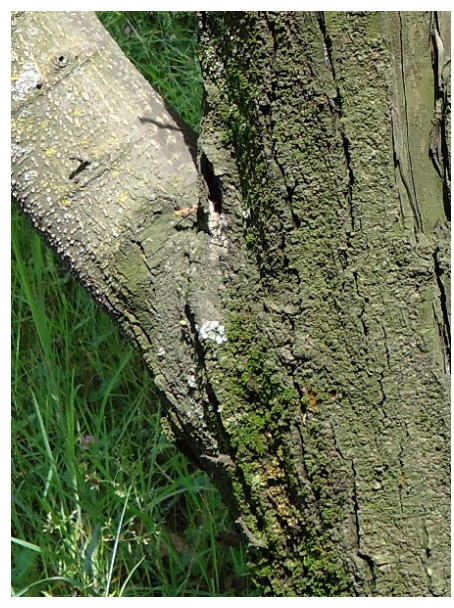

Figure 1

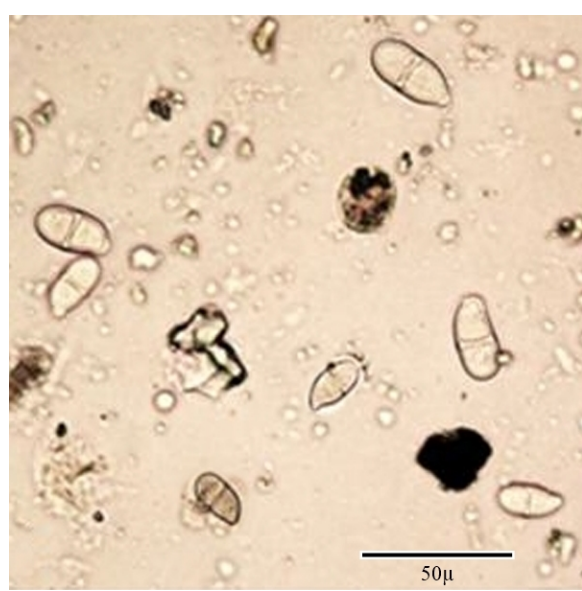

Figure 2

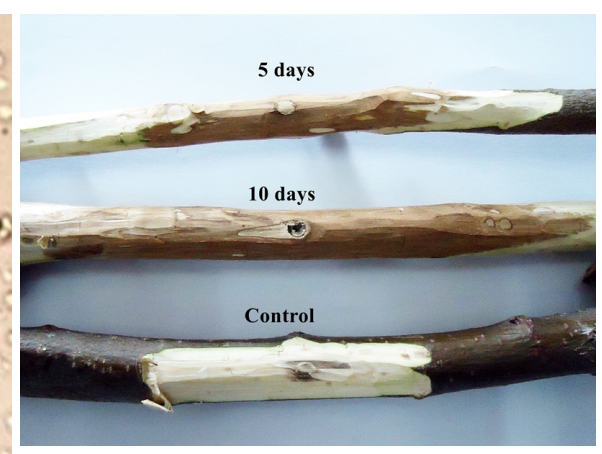

Figure 3

To cite this report: Dar M, Rai M, 2017. First report of Diplodia seriata causing canker on Castanea sativa in India. New Disease Reports 35, 19. http://dx.doi.org/10.5197/j.2044-0588.2017.035.019 